\title{
Advanced atrial myxoma in rural African setting
}

\author{
Peter McKavanagh, Karen Booth, Bharathi Varadarajan, O C Nzewi
}

CrossMark

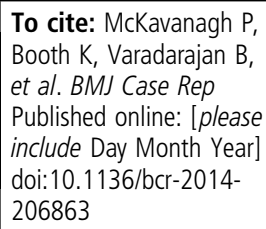

Royal Victoria Hospital, Belfast, UK

\section{Correspondence to} Dr Peter McKavanagh, mckavanagh@doctors.net.uk

Accepted 3 October 2014

\section{DESCRIPTION}

A woman is her 50 s presented to a rural African setting with shortness of breath and weight loss. She was treated unsuccessfully for tuberculosis, and was eventually referred to a cardiologist in a larger centre who diagnosed an atrial mass. Unfortunately due to lack of availability of surgical intervention she was treated medically for a number of months with diuretics. When our mission arrived she was anaemic, having symptoms of haemoptysis and a positional diastolic murmur. ECG showed sinus rhythm with left atrium (LA) enlargement. Transthoracic echocardiogram (figure 1A, B) showed a large mass in the LA collapsing through the mitral valve and a decision was made to urgently intervene. Being a Jehovah's Witness with haemoglobin of $80 \mathrm{~g} / \mathrm{L}$ meant intraoperative blood conservation strategies were essential, with the use of haemofiltration and cell salvage employed for haemoconcentration. Intraoperative transoesophageal echocardiogram demonstrated the origin of the lesion was from the intra-atrial septum and measured approximately $1.5 \mathrm{~cm}$ (video 1 ). Surgical approach was transeptal via the right atrium, removing a mass measuring approximately $6.5 \mathrm{~cm}$ long (figure 1C).

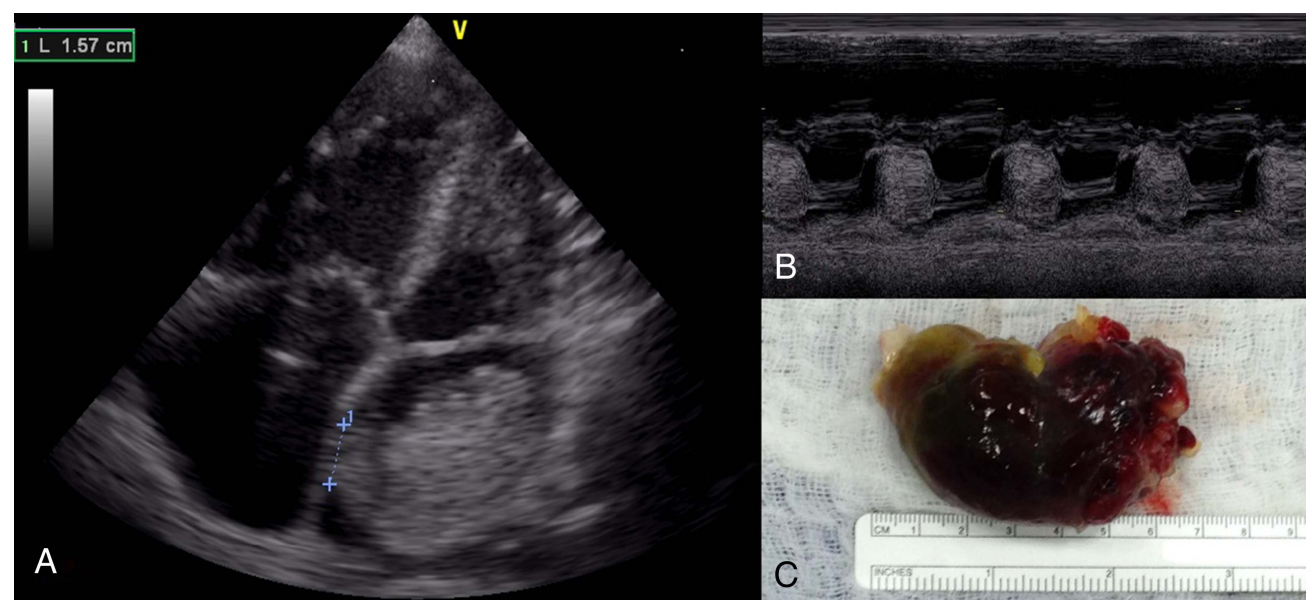

Figure 1 (A) Echocardiogram four-chamber view, demonstrating the length of the stalk; (B) M-Mode image (C) gross pathology after surgical removal.

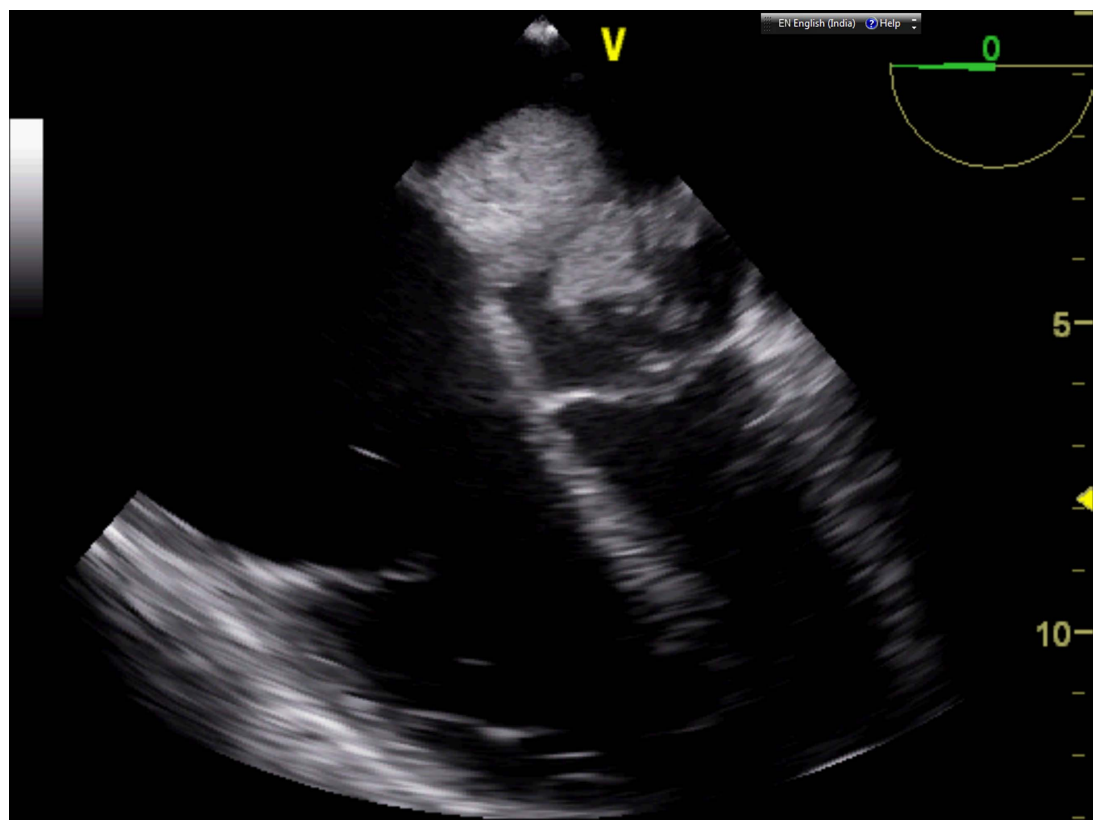

Video 1 Transoesophageal echocardiogram showing the prolapsing nature of the tumour and secondary right heart enlargement. 
Although traditionally seen as a Western disease, the incidence of cardiovascular disease is rising in developing countries. ${ }^{1}$ Although it is quite common to see cases of rheumatic, infective and uncorrected congenital disease, 'western' cardiac conditions

\section{Learning points}

- Atrial myxoma after tuberculosis and mitral stenosis, is a rarer cause of haemoptysis and shortness of breath in Africa. Although easily treated in the western world, surgical intervention is not widely available.

- Cardiovascular disease is becoming a major problem in developing countries. The need for cardiac intervention and education is increasing. are also often present, and generally present with advanced disease. Unfortunately many patients encounter a lack of diagnostic and interventional expertise. Medical missions can bridge this gap, although there must be a large emphasis on education. $^{2}{ }^{3}$

Acknowledgements The authors would like to thank rest of the Save a Heart Cardiac Mission Team.

Competing interests None.

Patient consent Obtained.

Provenance and peer review Not commissioned; externally peer reviewed.

\section{REFERENCES}

1 Mathers CD, Salomon JA, Ezzati MS, et al. Burden of disease and risk factors. New York: Oxford University Press, 2006.

2 Jonas RA. Rewards, risks, and responsibilities of globalization for the cardiothoracic surgeon. J Thorac Cardiovasc Surg 2007;134:1-14.

3 Cox JL. Presidential address: changing boundaries. I Thorac Cardiovasc Surg 2001;122:413-18.

Copyright 2014 BMJ Publishing Group. All rights reserved. For permission to reuse any of this content visit http://group.bmj.com/group/rights-licensing/permissions.

BMJ Case Report Fellows may re-use this article for personal use and teaching without any further permission.

Become a Fellow of BMJ Case Reports today and you can:

- Submit as many cases as you like

- Enjoy fast sympathetic peer review and rapid publication of accepted articles

- Access all the published articles

- Re-use any of the published material for personal use and teaching without further permission

For information on Institutional Fellowships contact consortiasales@bmjgroup.com

Visit casereports.bmj.com for more articles like this and to become a Fellow 